\title{
What motivational factors influence Students' Interest in Sales Career? An Empirical Investigation in Malaysia
}

\author{
Muhammad Khalilur Rahman* ${ }^{1}$, Masilah Mohamad ${ }^{1}$ and Abdul Highe Khan ${ }^{1}$ \\ International Islamic University Malaysia, Faculty of Economics and Management Sciences, Department of \\ Business Administration, Gombak, 53100, Selangor, Kuala Lumpur, Malaysia
}

\begin{abstract}
The purpose of this study is to explore various motivational factors to college students' interest in sales career. After assessing those factors we were able to determine the best predictor of motivational factors to college students' interest in sales career. A total of 130 respondents were obtained from students in International Islamic University Malaysia (IIUM) and Multimedia University (MMU) in Malaysia. The data was examined by using demographic information, reliability analysis, independent paired t-test, pearson correlation, paired samples correlations and hypothsis testing. The findings of the study revealed that personal development, communication skills and inner circle influence have most significant relationship with students' interest in sales carrer at $p=0.00$ (2-tailed) level. The result also revealed that paired sampls correlation of all constructs was significant at $p<0.01$ level. The main contribution of the study is that, the results of this study would assist the business firm in Malaysia in their business plan. The findings of this research may also contribute to the improvement of business organizations for recruiting employees, managerial strategy and prudent marketing plan.
\end{abstract}

Keywords: Factors, College student, Students' interest, Sales career, Malaysia

\section{Introduction}

Professional selling is an integral part of the business world and represents a variety of exciting and challenging career opportunities for students (Bristow, Gulati and Amyx, 2006). Market economic worldwide are driven by the consumption of goods and services (Spillan and Totten, 2007).To continue the consumption process, we need sales people who are well trained with the skills to adapt to a continuous changing business environment. In such way, recruiting college graduates for sales jobs has become a major concern for corporate American in recent years (Amin et. al, 1995). Many business students initially enter the workforcethrough the sales field, and, consequently, there has beena continued interest in assessing said students' perceptionsof the sales field as a career path (Spillan and Totten, 2007). As noted by Stevensand Macintosh (2002, 2003), this "interest is fueledby the fact that college students make up a large andattractive pool of job candidates," recruiting companies"would like to know the reasons why students are or arenot attracted to sales" and professors want to "know whatrole education plays in students' attitudes and perceptionsof sales as a career."However, some studies like Dubinsky 1981; Honeycutt et al 1999 conclude that, students possess a generally negative opinion of sales careers. The reason for this negative sentiment may be embedded in the widely held perception that selling involves manipulating others and is not considered a reputable activity (Spillan and Totten, 2007). However some studies have concluded that the perception appears to be changing and improving (Swenson et al, 1993). Many of the previous studies were attempt to measure on the student preferences, perception and attitudes, focusing on gender base studies and race comparative studies (Sadiq, 2004). Due to that factor the purpose of this paper is to explore various motivational factors to college students' interest in sales career. To identify entire factor, we based our research base on the previous research result conducted by the previous researcher, whether or not any significant difference from the previous generated result. In the process of investigating the motivational factors to the students, students were asked about their opinion about knowledge about selling environment.

\section{Literature Review}

The important part of this project is to explore various motivational factors to college student'sinterest in sales career. General point of view, motivation is the key of success of sales people to success in sales career. There are various motivational factors which can lead college student to pursue their career in sales. Our research is based on the previous study conducted by; Castleberry (1990), Amin (1995), Charles (2002),Sohail (2004), Spillan (2007) andBristow, Douglas and et. al (2011).

*Corresponding author's e-mail: abd_khalil2@yahoo.com 


\subsection{Job Itself}

Today's sales job is more prestigious, responsible and rewarding than what is was in the past. In terms of job security students believe that today's salespeople is motivated more by the desire to succeed and excel in his/her profession than by the threat of being fired due to non-performance (Castleberry; 1990; Spillan, 2007). Weilbaker et al. (1992) found that job satisfaction, job alignment with student's goals, recruiter morale at the time of interview, the company's financial health and reputation were some of the most important attributes of a sales job. Other characteristics identified in the literature include the jobs reputation, growth prospects, and financial stability (Bergman et al., 1984; Wortruba et al., 1989) and the work environment of the company, compensation, job security and scope of advancement leading to job satisfaction location, responsibilities, and employee morale (Castleberry; 1990; Harris et al., 1987). Other than selling as choosing sales as career it will provide job independence and ability to voice their own opinions on the job (Lacy et al., 1983; Powel, 1984) more than the recruiters. Therefore we propose that:

\section{H1: Job itself is the motivational factors for college student's interest in sales career.}

People always relates career in sales provide high job security. Job security here refers to feeling good about your security within the company (Bristow et. al, 2011). Job security normally valued highly by salespeople nearing retirement age (Ingram et al, 2008). In such way students also take job security as an important value for them if they want to choose sales as their career. The salesperson ability to sell can give salesperson high income and a lifelong job security (Brian Tracy, 2004). No matter how many changes take place in the economy, there is always a need for top sales people. On top of that, career in sales also provide high status. Status here means being accorded various position-based aspects such as one's own secretary, nicely appointed office, selected parking place, or other prestige elements (Bristow et al., 2011). Castleberry's study revealed that as student participants looked to the future, job security and status became increasingly.

\subsection{Personal Development}

Personal development associated with the opportunity to develop and refine new skills and abilities (Castleberry, 1990; Bristow, 2011). Sales career job for college students gives an opportunity to express creativity through developing new ideas for products, packaging branding and advertising. There is a constant cycle of regular product improvements and updates as brands compete head to head on the shelf. There are also the new products that come out of nowhere to define a market. Sales people typically are not time clock puncher or clock watchers. They see time as an ingredient of opportunity. The exception may be retail sales where many salespeople begin and collect needed skill. Even so, retail sales give college students who are involved in sales career, hope for a better job that many other jobs in retailing do not have. As college students progress in their sales career, they will gain more independence. So therefore, personally college students have huge opportunity to gain knowledge by choosing sales career. Honeycutt and Ford (1995) indicated that the educational level of sales candidates is an important factor for companies selecting members of their global sales forces. Over the years many students have entered the work force through the sales field. Many of them have become sales managers and have moved into various levels of importance in many wealthy companies (Spillan, 2007). Based on this rationale, we hypothesize that:

\section{H2: Personal development is the motivational factors for college student's interest in sales career.}

Every sales person has ultimate achievement in their job career program. College students have also chance to achieve sales target. According to Castleberry (1990), and Bristow et. al. (2011) has explained that "The feelings associated with successful competition of a job, finding solutions to different problems or seeing the results of one's work". Most management consultants would agree that feeling a sense of achievement is a very powerful motivator. Leaders can help motivate their employees, improve employee satisfaction and increase productivity by setting up programs that will allow happening. Sales people work to set up attainable and realistic goals. If the task seems too large, too complicated or too overwhelming, the sales people will most likely feel disappointed. Most sales people are tired of repetitious tasks. By offering training sessions either internally or externally, leaders can stimulate and motivate their sales people. At the same time, the sales people become more curious and creative, learn new techniques and procedures, and improve on the old ones.Advancement is related to the opportunity for promotion based on one's ability. According to Wotruba and Simpson (1988), Castleberry (1990) "reported on a study 209 marketing seniors which asked them what hiring factors influenced their decision to accept or reject a job offer. The result indicated the highest ranking went to good opportunities for advancement". Salespeople are looking to advance or develop their careers; there is more than just a silver lining in all of this. There is a lining made of gold. As the confidence and wallets of the top salespeople in every company are shaken, the sales professional looking to make a move has the pole position. 
To take advantage of such a great starting point, the sales professional of college students have to step up activity levels. Activity is never a substitute for productivity; but activity drives productivity (Walker, 1977).

\subsection{Income}

The most of the important motivational factor is the income. This is because; students' preference for sales career is influenced more by associated characteristics of the financial benefits and decision making power than by the functional aspect of the job (Swenson, 1993; Amin, 1995). College students may have dramatic effects for earning money on the success of sales recruitment programs (Dubinsky \& O'Conner, 1983). The better performing sales person always thinks to earn extra income from their sales career program. Besides, most of the students want to provide his or her family members with financial help, for this reason they usually have a dream to earn more money from their sales job performance. Selling is a gainful profession. In sales, there is no ceiling on your income. If you are properly trained, are skilled, and are selling the right product in the right market, there is no limit in the amount of money you can make (Tracy, 2004). Sales job applicants also emphasize job location, compensation and encouragement for graduate study (Castleberry 1990; Posner 1981). Accordingly, we propose that:

H3: Income is the motivational factors for college student's interest in sales career.

\subsection{Communication skills}

Oral communication is so critical to the business field and to the sales field especially. Those who can communicate well have the ability to excel in a sales position (Spillan and Totten, 2007). Generally, college students are very expert in communications through the product sales and services. This is because, sales person easily communicate to the customers for selling their goods and services. According to Weilbaker and Merritt (1992), have been examined that "Sales employment of college students have alternative clear communication skills, ethics and moral values. They make relation with their consumers by moral activities". Female's job experience in sales career is more important to company reputation. Women have clear comprehensive communication skills more than males (Castleberry, 1990; Wortruba et al., 1989). Students' perceptual communication skills increase the company's image and reputation (Barat, and Spillan, 2009). The average number of college students who are involved in sales career, has been achieved their target and goals for their excellent communication skills and sales force strategy (Amin, 1995; Lenartowicz, 2002). Hence, we propose that:

H4: A Communication skill is the motivational factors for college student's interest in sales career.

\subsection{Extra Benefit}

Beside the fixed salary there is some fringe or extra benefits in sales career. A substantial fringe benefit package covering such aspects like personal protection (Castleberry, 1990; Bristow, 2011). The Ten most common replies obtained were travel, money, personality, sales fast talker, commission, appearance, products, high-pressure, and aggressive (Sadiq, 2004). According to Moncrief (1986), sales job involves travelling out of town and potentially spending the night out of town. In terms of age, older students were much more concerned with fringe benefits than their younger counterparts (Castleberry, 1990). Despite the persistent negative attitude towards the sales job, compensation of salespersons has improved substantially in the form of health benefits vacation, and flexible work hour ( Lill et al., 2007 and Spillan, 2007). Based on these related empirical findings, we offer the following hypothesis:

H5: Extra benefit is the motivational factors for college student's interest in sales career.

\subsection{Inner Circle Influence}

Inner circle is a person or a group of people who inspire, motivate, coach and encourage others. Inner circle is associated with family and friends. Every successful person has their own private inner circle. As, an inner circle in sales force career creates a social network friends to expand the business channels (Crant, 2000). The sales career tradition is strong in many families. Many children's careers follow in the footsteps of their parents or relatives. Numerous examples can be presented where sons and daughters have pursued the same professional sales careers as their mother, father, uncles, or other relatives. Selling is a preemptive career which has many dimensions. Gender, class standing, and family relationships are an important factor that affects the decisions to enter the profession of personal selling (Spillan, 2007). Gender, class standing, and family sales profession history affect the cognitive lens through which students, business, and non-business, perceive the sales profession as a career path. The students with some family members involved in the sales field tended to disagree that selling is a "dead-end job" while students who had a family member working in sales profession 
had more positive opinions in general in selling as a career. Family member's involvement in sales field was shown to bear an influence on perceptions (Spillan, 2007). Consequently, we hypothesized that:

H6: Inner circle influence is the motivational factors for college student's interest in sales career.

\section{Methodology}

Data for this research was collected from student through a self-administered survey. The sampling frame consisted of business students who were in their undergraduate degree program at International Islamic University Malaysia (IIUM) and Multimedia University (MMU). The students were from different areas of business courses (Economics, Finance, Marketing, management and also other departments) of two university between 18 March to 22, 2011. The institution in the sampling frame enrolled students for both gender (male and gender) without any form of discrimination. The surveys were divided into two different sections. Section A consist of variable which to access student interest in pursuing sales after graduations and various motivational factor which leads student to choose sales as a career. Under Section A, respondent were asked to give their agreement to the related variable based on 6-point Likert scale. The possible answers for this question ranged from strongly disagree to disagree, somewhat disagree to somewhat agree, and agree to strongly agree as the intermediate answer possibilities. The second part of the questionnaire (Section B), consist of question related to socio-demographic characteristics of the respondents. This includes; gender, marital status, age, academic majoring, years of study, father's and mother's occupation and whether or not the respondent have an experience in sales. A total of 130 respondents completed the survey.

\subsection{Sample}

A total of 130 useable respondents were obtained from students in International Islamic University Malaysia (IIUM) and Multimedia University (MMU). The sample had a majority of male respondents, 97 respondents compared to 33 female respondents. A total of 117 respondents which accounted for $90 \%$ of the respondent are single and 13 respondents are married. In favor of age, the highest percentage falls to below than 21 years old and 25 years old student which accounted for $37 \%$ from total respondents. Second is age of 21 years old which accounted for $17.7 \%$, followed by 23 years old with $15.4 \%, 26$ years old with $13.8 \%, 22$ years old with $8.5 \%$ and lastly 24 years old with a percentage of $7.7 \%$. By looking at the academic majoring, the highest percentage goes to others (other than business courses) which accounted for $52.3 \%$ and the lowest is general business which is $3.1 \%$. Majority of the students are in their first year of study. This relates to the highest percentage of age rage where the highest is the below than 21 years old respondents. A total of 50 respondents states that their father's occupation is in Professional/Managerial field while majority of the respondent's mother occupation is a housewife. In favor of the experience in sales, the weighted is almost equal where $50.8 \%$ of the respondents said that they have an experience in sales. A profile of the respondents is provided by Table 1 .

Table 1: Respondent Demographic Profile

\begin{tabular}{|c|c|c|c|c|c|}
\hline Demographic Factors & Frequency & Percentage & Factors & Frequency & Percentage \\
\hline Gender: & & & Marital Status: & & \\
\hline Male & 97 & 74.6 & Single & 117 & 90 \\
\hline Female & 33 & 25.4 & Married & 13 & 10 \\
\hline Age: & & & Academic Majoring: & & \\
\hline Below 21 years old & 24 & 18.5 & Marketing & 6 & 4.6 \\
\hline 21 years old & 23 & 17.7 & Finance & 19 & 14.6 \\
\hline 22 years old & 11 & 8.5 & Management & 13 & 10.0 \\
\hline 23 years old & 20 & 15.4 & Economic & 19 & 14.6 \\
\hline 24 years old & 10 & 7.7 & General Business & 4 & 3.1 \\
\hline 25 years old & 24 & 18.5 & Others & 68 & 52.3 \\
\hline 26 years old & 18 & 13.8 & & & \\
\hline Years of Study: & & & Mother's Occupation: & & \\
\hline First Year & 64 & 49.2 & Professional/Managerial & 27 & 20.8 \\
\hline Second Year & 18 & 13.8 & Sales Admin & 6 & 4.6 \\
\hline Third Year & 17 & 13.1 & Farming & 1 & 0.8 \\
\hline Fourth Year & 30 & 23.1 & Precision Production/Repair & 1 & 0.8 \\
\hline Have Selling Experience: & & & Operator/Laborer & 6 & 4.6 \\
\hline Yes & & & Currently Not Working/ & 4 & 3.1 \\
\hline \multirow[t]{2}{*}{ No } & 66 & 50.8 & Housewife & 83 & 63.8 \\
\hline & 64 & 49.2 & & & \\
\hline
\end{tabular}




\section{Research Findings And Discussion}

\subsection{Reliability Analysis}

Reliability is the extent to which a scale produces consistent result if repeated measurement is made on the characteristic (Sekaran, 2010). The coefficient is used to access reliability. In this study, reliability is tested by the Cronbach's alpha where the total scale of reliability varies from 0.765 to 0.955 (Table 2) which indicates a higher reliability of items in the questionnaire. Cronbach's alpha should be equal to or greater than 0.70 if it is to be valid (Hair et. al., 1992; Hair et al., 1995; Rahman et. al., 2010). According to Hair et. al. (1992); Rahman et. al. (2010); Haque et. al. (2012); Jalil et. al. (2013) stated that Cronbach's alpha was a commonly used method where the alpha coefficient values range between 0 and 1 with higher values indicating higher reliability of variables and the relevant items under them. Hair et al. (2010) illustrated that the strength of alpha coefficient range less than 0.6 indicates poor, 0.6 to 0.7 is moderate, 0.7 to 0.8 indicates good, 0.8 to 0.9 defines very good and greater than 0.9 indicates excellent.

Table 2: Reliability Analysis

\begin{tabular}{ll}
\hline Variable & Cronbach Alpha \\
\hline All variable & 0.955 \\
Interest in Sales Career & 0.883 \\
Job Itself & 0.826 \\
Personal Development & 0.837 \\
Income & 0.773 \\
Communication Skills & 0.792 \\
Extra Benefit & 0.765 \\
Inner Circle Influence & 0.802 \\
\hline
\end{tabular}

The findings showed that the Alpha value is 0.845 . The result portray the strength of association is excellent. The reliability analysis tested the variables in the questionnaire given to the respondents. The test was carried out only for the ordinal data that is the based on likert scale which is range from 1 for strongly disagree, 2 for disagree, 3 for somewhat disagree, 4 for somewhat agree, 5 for agree and 6 for strongly agree. The number of item tested is 45 variables.

\subsection{Independent Paired t-Test}

In conducting the research, researcher had come up with one general objective. This gives major concern to explore various motivational factors to college student's interest in sales career. Due to the fact, researcher had used Independent Paired t-test to measure which motivational factor that attracts student's interest in pursuing sales as a career after graduating from their undergraduate studies.

Table 3: Significant Independent Paired t-Test

\begin{tabular}{|c|c|c|c|c|c|}
\hline Relationship & Mean & Std. Deviation & Std. Error & t-value & $\begin{array}{l}\text { Sig.(2- } \\
\text { tailed) }\end{array}$ \\
\hline Interest in Sales Career <--- Job Itself & -0.09442 & 0.81167595 & 0.07118869 & -1.3263 & 0.187085176 \\
\hline Interest in Sales Career<---Personal & & & & & \\
\hline Development & -0.28729 & 0.724897578 & 0.063577723 & -4.51875 & 0.000000000 \\
\hline $\begin{array}{l}\text { Interest in Sales Career <---Income } \\
\text { Interest in Sales Career }\end{array}$ & -0.12212 & 0.710744264 & 0.062336396 & -1.95907 & 0.052261848 \\
\hline Communication Skill & -0.93943 & 1.409468093 & 0.123618529 & -7.59942 & 0.000000000 \\
\hline $\begin{array}{l}\text { Interest in Sales Career <---Extra } \\
\text { Benefit }\end{array}$ & -0.01763 & 0.765463285 & 0.067135571 & -0.26266 & 0.793229334 \\
\hline $\begin{array}{l}\text { Interest in Sales Career<---Inner Circle } \\
\text { Influence }\end{array}$ & 0.606725 & 0.909707762 & 0.079786649 & 7.604342 & 0.000000000 \\
\hline
\end{tabular}

Referring to Table 3 above, there are there independent variables that indicate most significant values with the mean \pm S.E.M. P $<0.05$ which are Personal Development, Communication Skill, and Inner Circle Influence. Besides that, there are another three variables that signified less significant values which are Job $(\mathrm{P}=0.1871)$, Income $(\mathrm{P}=0.0523)$ and Extra Benefit $(\mathrm{P}=0.7932)$. Hence, in order to answer the research objectives; Personal Development, Communication Skill and Inner Circle Influence was the major factor that influence student interest in pursuing sales career.

\subsection{Pearson Correlation}

Using an interval measurement of scale, (Sekaran, 2003) suggested that it would be appropriate to use Pearson Correlation. One of the first issues is to determine whether the correlation coefficient is statistically significant. The rules of thumb have been proposed to characterize the strength of the association between variables, based on their absolute size of the correlation coefficient. 
In order to test the derived hypothesis, researcher had used Pearson Correlation to measure whether or not each of the variables had a significant relationship with the dependent variable. In the literature review part, researcher had drawn six hypotheses according to the independent variables. The Pearson Correlation was test by using 2 -tailed test with a significant level at 0.01 .

Table 4: Paired Samples Correlation

\begin{tabular}{|c|c|c|c|c|c|c|c|}
\hline & $\begin{array}{l}\text { Interest in } \\
\text { Sales } \\
\text { Career }\end{array}$ & Job Itself & $\begin{array}{l}\text { Personal } \\
\text { development }\end{array}$ & Income & $\begin{array}{l}\text { Communication } \\
\text { skill }\end{array}$ & Extra benefit & $\begin{array}{l}\text { Inner circle } \\
\text { influence }\end{array}$ \\
\hline $\begin{array}{l}\text { Pearson } \\
\text { Correlation }\end{array}$ & 1 & $0.6007 * *$ & $0.6661 * *$ & $0.6482 * *$ & $0.2880 * *$ & $0.6111 * *$ & $0.5682 * *$ \\
\hline Sig. (2-tailed) & & 0.0000 & 0.0000 & 0.0000 & 0.0009 & 0.0000 & 0.0000 \\
\hline
\end{tabular}

** Correlation is significant at the level 0.01 level (2-tailed).

According to Table 4, the data showed that the correlation of all the variables was significant at $\mathrm{p}<0.01$. This showed that all the variable have significant relationship to the dependant variable. Therefore, the entire hypothesis accepted (Table 6).

Table 5: Correlation Strength of Association

\begin{tabular}{lll}
\hline Variable & Correlation Sig. (2-tailed) & Strength of Association \\
\hline Job Itself & 0.6007 & Substantial to Very Strong \\
Personal Development & 0.6661 & Substantial to Very Strong \\
Income & 0.6482 & Substantial to Very Strong \\
Communication Skill & 0.2880 & Low to Moderate \\
Extra Benefit & 0.6111 & Substantial to Very Strong \\
Inner Circle Influence & 0.5682 & Substantial to Very Strong \\
\hline
\end{tabular}

According to Table 5 above, all the independent variable shows a substantial to very strong correlation with the dependant variables which are significant at 2-tailed except for Communication skill (0.2880) which is low to moderate strength of association.

Table 6: Summaries of Hypothesis

\begin{tabular}{ll}
\hline Characteristics & Result \\
\hline H1: Job itself is the motivational factors for college students interest in sales career & Accepted \\
H2: Personal development is the motivational factors for college students interest in sales career & Accepted \\
H3: Income is the motivational factors for college student's interest in sales career. & Accepted \\
H4: A communication skill is the motivational factors for college student's interest in sales career. & Accepted \\
H5: Extra benefit is the motivational factors for college student's interest in sales career. & Accepted \\
H6: Inner circle influence is the motivational factors for college student's interest in sales career. & Accepted \\
\hline
\end{tabular}

\section{Conclusion And Implication}

Findings from this study suggest that, there are various motivational factors to college student's interest in sales career. We know that different people have different motivational factors that drive their interest of taking sales as their professional career. We have demonstrated in this study that there are different interest among students, the potential sales people of the future, and who they are as individuals. Specifically we have found that, what are best motivational predictors or factor that drives student to choose sales after graduation. Among the entire six motivational factors, three of them which are; Personal Development, Communication Skill and Inner Circle Influence was the major factor that influence student interest in pursuing sales career.

As for the implication of the research, there are major implications for the educator and sales professional recruiter. From the training point of view, it is necessary for educators and trainers to set specific goals regarding an area of sales. In favor of personal development elements, students seeks to choose sales as career as they believe they will be given a chance to enhance their career development. In such way, in favor of the educator, they must expose the student with what kind of benefit or area of personal development that student can achieve as they choose sales as a career. For example, they can expose the student by conducting a seminar where they can invite their previous student who had excelled in sales field. By doing this, the student will be more inspired to pursue in sales.

Second is in terms of communication skills. Communication skills are a very important element in determining the success and failure of sales people. If the sales people can communicate well their prospect customer it will be easier for them to close the sales. In such way, what educator and professional recruiter can do is they can provide communication skills class. Specifically, at the university level, communication skills should be added as an core subject where all student is compulsory to take the subject. Last but not least is in 
terms of inner circle influence. Inner circle influence deals with the people around the students such as the family and friends. These are the people who can influence the students to come up with the decision to choose sales as a career. The educator and professional recruiter can make a joint venture to conduct a career fair to induce student's interest in sales. From the career fair, student is being exposed what are the benefits if they joint sales field after graduating.

\section{References}

[1] Amin, S.G., Hayajneh, A.F. and Nwakanma, H. (1995). College Stuents' View of Sales Jobs as a Career: An Emprical Investigation, American Business Review.

[2] Brian Tracy (2004), The Psychology of Selling: How to Sell More, Easier, and Faster Than You Ever Thought Possible, Thomas Nelson Inc, Nashville, Tenesse.

[3] Bristow D., Amyx D., Stephen B., Castleberry and Cochran J.J. (2011). A cross generatonal Comparison of Motivational Factors in a Sales Career Among Gen-x and Gen-y college students, Journal of Personal Selling \& Sales Management, 31(1), 77-85.

[4] Castleberry S.B. (1990). Selling and Sales Management in Action: The Importance of Various Motivational Factors to College Students Interested in Sales Positions, Journal of Personal Selling \&Sales Management, 10, 67-72.

[5] Charles D., Stevens and Macintosh G. (2002). Personality and Attractiveness of Activities within sales jobs, Journal of Personal Selling and Sales Managenment, 23(1) 23-35.

[6] Crant, M.J. (2000). Proactive behavior in organizations, Journal of Management, 26(3), 435-462.

[7] Dubinsky and Alan J. (1980). Recruiting College Students for the Salesforce, Industrial Marketing Management, 37-45.

[8] Dubinsky, Alan, and P.J. O’Conner (1983). A Multimensional Analysis of Preferences for Sales Position, Journal of Personal Seling and Sales Management, 31-41.

[9] Hair, J. F., Anderson, R. E., Tatham, R. L., \& Black, W. C. (1992). Multivariate Data Analoysis (3rd ed.). Macmillan, New York.

[10] Hair, J., Anderson, R., TathaM, R., \& Black, W. (2010). Multivariate Data Analysis: A Global Perspective (7th ed.). Upper Saddle River, NJ: Pearson Prentice-Hall.

[11] Hair, J., Anderson, R., Tatham, R., \& Black, W. (1995). Multivariate Data Analysis with Readings (4th ed.). Englewood Cliffs, NJ: Prentice Hall.

[12] Haque, A., Sarwar, A. A., Yasmin, F., Anwar, A., \& Nuruzzaman, (2012). The Impact of Customer Perceived Service Quality on Customer Satisfaction for Private Health Centre in Malaysia: A Structural Equation Modeling Approach. Information Management and Business Review, 4(5), 257-267.

[13] Jalil, M. A., Razak, D. A., \& Azam, S. F. (2013). Exploring Factors Influencing Financial Planning after Retireemnt: Structural Equation Modeling Approach. American Journal of Applied Sciences, 10(3), 270-279.

[14] Lenartowicz, Tomasz and James P. Johnson (2002). Comparing Managerial Values in Twelve Latin American Couintries: An Exploratory Study, Management International Review, 42(3) 279-307.

[15] Moncrief, William C. (1986). Selling Activity and Sales Position Taxonomies for Industrial Salesforces, Journal of Marketing Research, 261-270.

[16] Rahman, S., Haque, A., \& Ahmad, M. I. (2010). Exploring Influencing Factors for the Selection of Mobile Phone Service Providers: A Structural Equational Modeling (SEM) Approach on Malaysian Consumers, African Journal of Business Management, 4(13), 2885-2898.

[17] Sekaran, U. (2010). Research Methods for Business: A Skill Building Approach (4th ed.). New York: John Wiley and Sons, Inc.

[18] Sohail M.S. (2004). Influence of Ethnicity on Students' Sales Career Preference: Some Observation from a Developing MultiRacial Country, Problem and Perspective in Management, No.1.

[19] Spillan, J.E, Totten, J.W. and Ziemnowicz, C. (2007). What are students' perception of personal selling as a career?, Journal for Advancement of Marketing Education, 11.

[20] Thomas N. Ingram, Raymond W. LaForge, Ramon A. Avila (2008), Sales Management Analysis and Decision Making, M.E Sharp Inc, $7^{\text {th }}$ Edition, United States of America

[21] Uma Sekaran (2003) Research Methods for Business, $4^{\text {th }}$ Edition, John Wiley \& Son, USAWalters and Bergeil (1989). "The Revolution in Distribution: Challenges and Opportunuties", Long Range Planning 30(6), 823-829, USA.

[22] Walker, Orville C., Jr., Gilbert A. Churchill, JR., and Neil M. Ford (1977). Motivation and Performance in Industrial Selling: Personal Knowledge and Needed Research, Journal of Marketing Research, 14, 156.

[23] Weilbaker, Dan C. \& Merritt and Nancy J. (1992). Attracting Graduates to Sales Positions: The Role of Recruiter Knowledge, Journal of Personal Selling and Sales Management, 12(4), 49-57.

[24] Wertz, Barton A. Harish Sujan and Mita Sujan (1986). Knowledge, Motivation, and Adaptive Behavior: A Framework for Improving Selling Effectiveness, Jouranal of Marketing, 174-191.

[25] Wotruba, Thomas R., Edwin K. Simpson and Jennifer L., Reed-Draznik (1989). The Recruiting Interview as Perceived by College Student Applications for Sales Positions, Journal of Personal Selling and Sales Management, 9. 